\title{
Oncological sensitivity. Report of the training conducted for primary health care physicians in the Holycross Cancer Center
}

\section{Wrażliwość onkologiczna. Sprawozdanie ze szkoleń dla lekarzy podstawowej opieki zdrowotnej zorganizowanych w Świętokrzyskim Centrum Onkologii}

\author{
Ewa Błaszkiewicz ${ }^{1,2}$, Michał Chrobot³ , Paweł Macek²,4, ${ }^{2, \text { Halina Król6,7, Małgorzata Terek-Derszniak }}$, \\ Stanisław Góźdź8,9 \\ ${ }^{1}$ Department of Education, Jan Kochanowski University, Kielce, Poland \\ Head of the Department: Agnieszka Świerczek MA \\ 2Department of Epidemiology and Cancer Control, Holycross Cancer Center, Kielce, Poland \\ Head of the Department: Paweł Macek PhD \\ ${ }^{3}$ Department of Contracting, Accounting and Medical Statistics, Holycross Cancer Center, Kielce, Poland \\ Head of the HCC: Stanisław Góźdź MD, PhD, Assoc. Prof. JKU \\ ${ }^{4}$ Department of Rehabilitation, Holycross Cancer Center, Kielce, Poland \\ Head of the Department: Anna Opuchlik PhD \\ ${ }^{5}$ Faculty of Medical Sciences, School of Economics, Law and Medical Sciences, Kielce, Poland \\ Head of the Faculty: Grzegorz Gałuszka PhD \\ ${ }^{6}$ Department of Science, Holycross Cancer Center, Kielce, Poland \\ Head of the HCC: Stanisław Góźdź MD, PhD, Assoc. Prof. JKU \\ 'Department of Developmental Age Research, Institute of Public Health, Faculty of Medicine and Health Sciences, \\ Jan Kochanowski University, Kielce, Poland \\ Head of the Institute: Grażyna Nowak-Starz PhD, Assoc. Prof. JKU \\ ${ }^{8} \mathrm{Clinic}$ of Clinical Oncology, Holycross Cancer Center, Kielce, Poland \\ Head of the Clinic: Stanisław Góźdź MD, PhD, Assoc. Prof. JKU \\ ${ }^{9}$ Department of Cancer Prevention and Epidemiology, Institute of Public Health, Faculty of Medicine and Health Sciences, \\ Jan Kochanowski University, Kielce, Poland \\ Head of the Department: Prof. Stawomir Dutkiewicz MD, PhD
}

Key words: diagnosis, cancer, primary health care.

Słowa kluczowe: diagnostyka, nowotwór, podstawowa opieka zdrowotna.

\begin{abstract}
The aim of this report is to describe the series of training sessions for primary health care (PHC) physicians that concerned "oncological sensitivity" and were organized in the Holycross Cancer Center (HCC) in the first quarter of 2015. The purpose of the training sessions was to present the guidelines of the oncological fast-track system and the practical information with respect to disturbing symptoms of the disease and the necessary diagnostics directed at verifying the suspicion of various types of cancer. This knowledge allows the proper implementation of the tasks entrusted to the family doctor as part of the Oncological Package. Practical training (medical) was conducted by specialists working in several different clinics within the Holycross Cancer Center. The theme of the meetings covered all types of cancer, from solid tumors of various locations to tumors of the hematopoietic system.
\end{abstract}

\section{Streszczenie}

Sprawozdanie ma na celu przybliżenie tematyki cyklu szkoleń dla lekarzy podstawowej opieki zdrowotnej (POZ) dotyczących tzw. wrażliwości onkologicznej, które zorganizowano w Świętokrzyskim Centrum Onkologii (ŚCO) w pierwszym kwartale 2015 r. Zadaniem spotkań szkoleniowych było przybliżenie zasad funkcjonowania szybkiej ścieżki onkologicznej oraz prezentacja praktycznych informacji na temat niepokojących objawów chorobowych i zakresu niezbędnej diagnostyki mającej na celu weryfikację podejrzeń poszczególnych nowotworów złośliwych. Wiedza ta umożliwia właściwą realizację zadań powierzonych lekarzowi rodzinnemu w ramach realizacji pakietu onkologicznego. Szkolenia praktyczne (medyczne) przeprowadzili specjaliści pracujący w kieleckich klinikach onkologii. Tematyka spotkań obejmowała wszystkie typy nowotworów - od guzów litych poszczególnych lokalizacji aż po nowotwory układu krwiotwórczego. 


\section{Introduction}

Care for cancer patients, along with the implementation of the so-called Oncological Package on the $1^{\text {st }}$ of January 2015, took on a new dimension. The Oncological Package is a colloquial term for legal acts (amendments to the Law of healthcare services financed from public funds [1], regulations of the Minister of Health or ordinance of the President of the National Health Fund (Polish abbreviation: NFZ)), introducing the possibility of rapid diagnosis and oncological treatment. Changes made by the Oncological Package are designed to improve access to diagnostics and treatment for patients with cancer and to systematize the diagnostic and therapeutic process.

This allows, among other things, the introduction of the diagnosis and oncological treatment card, the so-called "green card", and the setting of a maximum time limit to accomplish the particular stages of diagnosis and treatment.

The time limits for performing full oncological diagnostics (i.e. the time since entering the patient on a waiting list for a consultation with a specialist in order to diagnose should be no longer than 9 weeks in 2015,8 weeks in 2016, and 7 weeks from 2017) enable the immediate beginning of appropriate oncological therapy, and, if they are met, also will allow the payment for diagnostics and treatment of cancer without limits from the National Health Fund.

One of the key solutions of the Oncological Package is the introduction into clinical practice of a multidisciplinary approach to cancer treatment that is provided by meetings of multidisciplinary therapeutic teams (MTT) (consisting of medical specialists in the fields of surgery, oncology or hematology, radiotherapy or nuclear medicine and radiology and diagnostic imaging), during which the optimal individual treatment plan is determined for each patient according to the stage of the disease and general condition of the patient. Another important change is the obligation to launch the first therapies within the framework set by the MTT treatment plan within 14 days from the date of consultation. The coordinators, appointed by the MTT after determining the therapeutic path, are responsible for setting time limits and direct the patient's contact with the medical facility (at all stages of the therapy) [2]. The solutions introduced by the Oncological Package included especially the detection of neoplastic lesions at an early stage and the support for patients in medical centers. This legitimizes extending the diagnostic powers of the primary health care (PHC) physician as well as allowing him to prepare the DiLO card (Polish DiLO card - CD\&T - Cancer Diagnosis and Treatment card) for the patient in case of cancer suspicion. In response to the introduction of a rapid oncological treatment and the increased role of PHC physicians in the detection of cancer and the care of patients after cancer treatment, the Holycross Cancer Center (HCC) has launched its own initiative, a series of free training sessions for doctors of these institutions concerning "oncological sensitivity", including the core symptoms and the extent of the necessary diagnostics, aimed at verifying the suspicions of various types of cancer. This type of training also took place in other provinces, and it was an initiative independent of regional or clinical oncology centers, which are the backbone of cancer care in Poland and where the vast majority of all cancer patients are treated. Training sessions were held in Professor Tadeusz Koszarowski's lecture hall in the administrative building of the Holycross Cancer Center at 3C Artwińskiego Street in Kielce. In response to the e-mail invitations sent to PHC centers, all the meetings were attended by nearly 160 participants - primary health care physicians from all over the Świętokrzyskie voivodship. The theme of the meetings covered all types of cancer from solid tumors of various locations to hematopoietic malignancies.

The meetings were divided into medical specialties (two specialties for one day of training), so that each participant could take part in the meetings regarding types of cancer that they were interested in. Specific types of training, thematically related to groups of organs, were preceded by an organizational meeting where participants were provided with basic information about the assumptions of rapid diagnosis and oncological therapy, as well as the role of the Holycross Cancer Center and state of preparations for the implementation of the Oncological Package in Świętokrzyskie province. That meeting took place on the $9^{\text {th }}$ of December 2014 on the initiative of the director of the Holycross Cancer Center, Assoc. Prof. Stanisław Góźdź MD, PhD, and Mrs. Zofia Wilczyńska, the director of the Świętokrzyskie Branch of the National Health Fund (Polish abbreviation: NFZ ŚwOW). It was dedicated to all providers interested in the subject of the Oncological Package, including hospitals, specialist out-patient clinics and primary health care physicians.

Participants of the organizational meeting and invited guests were welcomed by the director of the HCC, Assoc. Prof. Stanisław Góźdź MD, PhD, and the director of the National Health Fund in Świętokrzyskie province, Mrs. Zofia Wilczyńska. Later in the meeting, Michał Chrobot, MSc, Head of the Department of Contracting, Accounting and Medical Statistics HCC, presented the main assumptions of the Oncological Package, according to the Ministry of Health. Then Prof. Stanisław Goźdź MD, PhD, presented the current capacities of the HCC in terms of ongoing patients support (including patients with the DiLO card) and assumptions of the Oncological Package based on cooperation between external partners and the Holycross Cancer Center, in terms of organization as well as diagnostics and treatment. The organizational 
meeting ended with an invitation to participate in the practical training (medical) and conclusion of written agreements with the HCC concerning cooperation in the implementation of cancer care in the region.

The first specific training session was held on the $28^{\text {th }}$ of January 2015 and covered the subject of breast cancer, gastrointestinal tract cancer, sarcomas and melanomas. The next training was held on the $11^{\text {th }}$ of February 2015 and concentrated on urogenital cancer in men and women. The next meeting, on the $4^{\text {th }}$ of March 2015, was devoted to lung cancer and malignant neoplasm of pleura and palliative care in oncology. The last training, in which cancers of the head and neck, hematopoietic tissue and endocrine glands were discussed, took place on the $18^{\text {th }}$ of March, 2015. In order to properly organize training sessions the participants were always obliged to report their presence via e-mail sent to the address onkoline@onkol. kielce.pl, no later than 3 days prior to the date of the planned meeting.

\section{Breast cancer and gastrointestinal tumors, sarcomas, melanomas}

The official opening of the training cycle for PHC physicians was performed be the director of the Holycross Cancer Center, Prof. Stanisław Goźdź $\mathrm{MD}, \mathrm{PhD}$. The next speaker was the Marshal of the Świętokrzyskie voivodship, Mr. Adam Jarubas, who encouraged the audience to cooperate with the Holycross Cancer Center, the only fully profiled oncology center in Świętokrzyskie province, which made the effort to organize and coordinate cancer care for patients from all over the province. The introduction to the practical part of the training was to determine the epidemiological situation of breast cancer, gastrointestinal cancer, sarcomas and melanomas in Świętokrzyskie and was presented by Paweł Macek $\mathrm{PhD}$, from the Department of Cancer Epidemiology of the HCC (the co-author of lectures on epidemiology of cancers of all organ groups was Assoc. Prof. Stanisław Góźdź, MD, PhD, Head of the Department of Clinical Oncology and Director of the HCC).

Doctor Paweł Macek presented figures in terms of morbidity and mortality from breast cancer among women in 2012, according to stage (local, regional, generalized) and structure (invasive cancers and pre-invasive) in the years 1999-2012. In the case of tumors of the gastrointestinal tract and digestive organs as well as sarcomas and melanomas, presented data on morbidity and mortality for these cancers in 2012 were divided according to sex of the patient. At the end of the lecture, he discussed age-standardized 5 -year relative survival rates in the Świętokrzyskie region in the years 2005-2009, based on the test results obtained by the project CONCORD 2, in which the HCC participated.
The next speaker was Paweł Sękowski MD, PhD, from the Department of Surgical Oncology, Thoracic Surgery Unit of the HCC, who presented the problem of cancer of the digestive system. He discussed their classification (ICD-10), then in detail the issues associated with gastric cancer (GIST tumors derived from gastrointestinal stroma) and colon cancer. He characterized the factors that contribute to the development of disease, clinical symptoms and diagnostic methods of cancers of the digestive system. He broadly explained indications for gastroscopy and colonoscopy. He also presented a screening program for early detection of colorectal cancer, the most common malignancy of the digestive system in Poland the risk group and screening methods (one- and twostage). He also discussed methods of treatment (basic and supplementary) of stomach cancer, GIST and colorectal cancer, and the principles of observation of patients after treatment - recommendations for visits and checkups.

Information about pancreatic cancer and cancers of the liver and bile ducts was presented by Monika Olszewska MD, representative of the Department of Surgical Oncology, Thoracic Surgery Unit of the HCC. She discussed the pancreatic types of cancer and their risk factors. She explained the etiology and clinical symptoms of pancreatic cancer, including location of the tumor (head, body and tail of the pancreas). Then she discussed the diagnostic methods and treatment of pancreatic cancer and resectable tumors, for which surgical treatment is accepted as the gold standard, as well as the treatment of unresectable (inoperable) tumors. Also recommendations on follow-up after treatment (scheduled follow-up visits and recommended tests) were explained.

Another group consisted of cancers of the liver and bile ducts. The classification of liver tumors presented during the lecture included benign tumors, cancers and lesions of the liver. Then M. Olszewska discussed the etiology of hepatocellular cancer, the most common liver cancer, symptoms of primary liver cancer (in the interview with the patient and physical examination) and its diagnosis. Later, she analyzed the treatment of primary and metastatic cancers and the selection criteria for their treatment and palliative care. The last group consisted of biliary tract cancers - their types, pathology, etiology, clinical symptoms, diagnosis, treatment and post-treatment observation.

Another lecture on the diagnostics and treatment of breast cancer was presented by Piotr Kędzierawski $\mathrm{MD}, \mathrm{PhD}$, Head of the Breast Cancer Unit at the HCC. He discussed the epidemiological situation in Poland, risk factors, primary (to a lesser extent) and secondary prevention, supplemented by data on the implementation of a screening program for early detection of breast cancer in Poland and Świętokrzyskie province. In the lecture he presented clinical symptoms of 
breast cancer, the scope of medical examination (subjective and objective) and diagnostic imaging tests - basic (mammography) and complementary (ultrasound). The lecturer also discussed the indications and desirability of other studies in the diagnosis of lesions in the breast - magnetic resonance imaging (MRI), computed tomography (CT) and positron emission tomography (PET). Then he considered the scope of histopathological tests (using core needle and mammotome biopsy), the outcome of which is the basis of breast cancer diagnosis. He discussed different kinds of tests done to determine the stage of the disease (chest X-ray, abdominal ultrasound, blood tests and - at higher levels of severity of the disease - CT scans of the chest, abdomen, pelvis bone scan and blood tests), evaluation of clinical stage cancer, based on the TNM classification (Tumor - Nodes - Metastasis) and methods for their treatment (surgery, radiotherapy, chemotherapy, hormonal therapy, biological therapy). At the end of his presentation, he outlined principles of observation of patients after treatment (for early detection of recurrence) and the rehabilitation of patients after breast cancer treatment.

Sławomir Trepka MD, PhD, from the Clinic of Surgical Oncology with Thoracic Surgery Unit of the HCC, conducted training covering symptoms and recognition of melanoma, osteosarcoma (bone cancer) and soft tissue sarcoma.

To begin with he characterized malignant melanoma (skin cancer) and discussed the prognosis of such disease, dependent on clinical and histological factors and anatomical location. Then he discussed the scale of the incidence of melanoma in Poland in comparison to the United States, factors that increase the risk of developing this type of cancer, principles of primary prevention (aimed mainly at avoiding excessive, intentional tanning) and classification based on clinical and pathological features. Next, he analyzed the prognostic factors and characteristic symptoms of melanoma and dermoscopy, which is the basis of clinical differential diagnosis and qualification for excisional biopsy. At the end of the meeting participants were familiarized with the methods of treatment, according to the stage of melanoma.

During another speech, Sławomir Trepka MD, $\mathrm{PhD}$, described a rare type of cancer - osteosarcoma. He presented early and late symptoms as well as the most common location of this group of tumors. Then he explained tests used in the diagnosis of bone sarco$\mathrm{ma}$ - the primary method of imaging, i.e. roentgenography of the entire bone (X-ray) and applied research in the following diagnosis to assess local tumor stage (MRI and CT), bone scintigraphy which allows one to exclude changes in other parts of the skeleton or supported examinations by the use of positron emission tomography studies including computed tomography (PET-CT) in order to assess the progress of small-cell sarcomas. The speaker also emphasized the need to perform X-ray/CT of the chest in order to exclude metastases (in $20 \%$ of patients diagnosed with osteosarcoma, metastases occur in the lungs) and biopsies, which enable collection of samples for tissue examination, on the basis of which the final diagnosis of bone sarcoma is determined.

The third, closing lecture of Sławomir Trepka MD, $\mathrm{PhD}$, was devoted to sarcomas of soft tissues (STS). After describing their characteristics he discussed anatomical location and STS clinical symptoms. Then he explained the scheme of diagnostic procedures for soft tissue sarcoma - from imaging tests (X-ray), through computed tomography (CT), magnetic resonance imaging (MRI) to spiral CT with contrast. He stressed that the basis for the identification and evaluation of prognostic factors in STS is the result of a histopathological examination of the material obtained through diagnostic biopsy, carried out after the imaging tests.

\section{Neoplasms of the urogenital system among the female and male population}

Epidemiology of cancers of the urogenital system of women and men in Świętokrzyskie province in 2012 was presented by Paweł Macek, PhD, from the Department of Cancer Epidemiology of the HCC. In the first place, he discussed cancers of urinary tract (C64-C68), including bladder (C67), followed by cancers of male genital organs (C60-C63), including prostate cancer (C61) in men - the number of cases and deaths as well as its structure. The corresponding figures were presented for cancers of the urinary tract and female genital tract regarding women of Świętokrzyskie voivodship in 2012.

The next speaker was Mateusz Obarzanowski MD, Deputy Head of the Urology Department of the HCC, who presented the classification of "urological" tumors (according to ICD-10). He described the relationship of their occurrence with age (especially in the elderly) and difficulty in diagnosis and treatment of urological tumors, accounting for $35 \%$ of all cancers concerning men. The scale of the problem was demonstrated in the case of a rare testicular cancer with incidence of all cancers at the level of 1\% they are the most common cancers in men aged 15-39 years, constituting the first cause of death among men in this age group. At the end of the lecture, he defined methods of performing diagnosis of neoplasms of the urogenital system with regard to individual diagnosis (history, physical examination and additional tests PSA (prostate specific antigen) and ultrasound).

Another lecture was given by Leszek Smorąg $\mathrm{MD}, \mathrm{PhD}$, from the Department of Gynecology of the HCC. He concentrated on types of cancers with respect to the female reproductive system. He began by explaining the historical data (since 1987) on the incidence and deaths from these cancers in Poland, 
mortality rates and percentage chance of recovery. Then, he clarified the clinical symptoms, diagnosis, components and objectives of medical history, risk factors and the scope of the medical and gynecological examination of female genital types of cancers including cervical, endometrial, ovarian, vaginal and vulvar cancer.

The topic of urinary tract cancers was discussed by Marcin Kosowski MD from the Department of Urology of the HCC. The speaker characterized in detail the occurrence of specific cancers, described the relationship between the incidence and age and gender (the risk of cancer of the urinary tract is nearly 4 -fold higher in men than in women), risk factors, clinical symptoms, and diagnostic methods. Then, he focused on the possible methods of treatment for this group of cancers and recommendations for followup of patients after treatment. Bladder cancer is the most common type among malignant neoplasms of urinary organs, which constitutes approximately 7\% of all malignant tumors and is more frequently diagnosed in men. In conclusion, the speaker described hematuria as a frequent manifestation of the disease of the urinary tract. He explained that macroscopic hematuria is always an alarming symptom, though not always an indicator of tumors. If it occurs, the necessary step to be taken is to perform diagnostic tests to determine its cause and exclude the presence of other lesions in the urinary tract (e.g. blood coagulation disorders, urolithiasis, urinary tract infection) requiring appropriate treatment.

At the end of all the lectures, Tomasz Tomaszewski MSc, President of IRONTeam Ltd., spoke. He presented the principles and functionality of the internet platform called ONKOline, which is a tool created in order to support PHC physicians in delivering the Oncological Package. He explained the objectives of founding the platform (for PHC physicians and patients), rules of registration and the process of generating individual accounts for PHC physicians. He emphasized that registration in ONKOline is a confirmation of being a partner of the Holycross Cancer Center, which cooperate with the platform and is confirmed by the certificate. Possession of the certificate by the medical practitioner is a statement for the patient that in this particular doctor's office in case of cancer suspicion, the patient receives comprehensive advice and is referred to an appropriate specialist.

\section{Lung and pleural cancers and palliative medicine in cancer diseases}

Similarly to the previous training meetings, Paweł Macek PhD, from the Department of Cancer Epidemiology of the HCC, began by presenting the epidemiological data of lung and pleural cancer as well as the head and neck cancers in Świętokrzyskie voivodship.
His presentation concentrated on figures regarding morbidity and mortality from lung and bronchial cancer among women and men in 2012, also in relation to other common types of cancer. Then Paweł Macek $\mathrm{PhD}$, demonstrated a similar range of statistical information of the heart, mediastinum and pleural cancers (malignant neoplasms of intrathoracic organs) as well as head and neck cancers.

The next speaker was Jakub Perdeus MD, Deputy Head of the Department of Surgical Oncology with Thoracic Surgery Unit of the HCC, who spoke about cancers of the respiratory system. To begin with he presented the classification of cancer types according to their location and the starting point. Then he discussed in detail the epidemiological data for Poland, also in relation to other countries in Europe, and the etiology of this cancer. The next part of his speech was focused on the possibilities of primary and secondary prevention of lung cancer. Then the speaker discussed in detail the histological classification according to the World Health Organization and TNM classification of lung cancer. Subsequent information was related to symptoms, diagnostic tests and diagnostic treatment indicated in order to verify suspicion of lung cancer. Primary health care physicians were acquainted with the detailed diagnostic algorithm in the case of patients experiencing tumor in the lung. Next were basic standards of treatment in lung cancer applied in Poland, in various stages of disease. The lecture ended with the presentation of data on the average percentage of 5-year survival in patients with lung cancer depending on the individual stages of progression.

Another lecture was delivered by Leszek Mierzwa MD, PhD, Head of the Department of Palliative Medicine of the HCC. He presented the problems related to palliative and hospice care therapy and treatment of pain regarding patients in the terminal stage of cancer. As part of the introductory speech he discussed the principles, organization and legal basis of palliative and hospice care in Poland, in Świętokrzyskie province and in the Holycross Cancer Center. Then, the speaker explained the principal challenge for doctors who are responsible for patients in the terminal condition of cancer, i.e. appropriate treatment of pain. Statistics on the issue of pain in Poland, including the prevalence of pain in patients with advanced cancer, were the next step in the presentation. The speaker discussed the types of pain occurring in cancer patients and their causes. In the next part of his speech, he presented the rules of applying the WHO's analgesic ladder (World Health Organization), which helps to alleviate cancer pain. He discussed in detail breakthrough pain along with the current capabilities of therapy, including the current guidelines for the reimbursement of medicines and dressing materials in Poland. Finally, he discussed in detail the treatment 
of other types of cancer pain, including invasive and non-invasive methods.

\section{Neoplasms of the head and neck, hematopoietic system and endocrine glands}

The next meeting for PHC physicians was started by Paweł Macek PhD, from the Department of Cancer Epidemiology of the HCC, who presented the epidemiology of cancers concerning the lymphatic system, hematopoietic system and endocrine glands in Świętokrzyskie voivodship in 2012. He presented in detail the figures in terms of morbidity and mortality of cancer of the lymphatic and hematopoietic system among women and men in 2012. In the following part of the lecture, he presented a similar set of data for cancer of the endocrine system, of which a major health problem is thyroid cancer in over $84 \%$ of cases concerning women.

The next lecture was given by Aldona Kowalska $\mathrm{MD}, \mathrm{PhD}$, Head of the Department of Endocrinology of the HCC. In the speech, she referred to the problem of cancer in the field of endocrinology in the context of, introduced in 2015, the Oncological Package. One by one she discussed diagnostic tasks recommended to perform when examining a patient with nodular goiter (interview, palpable examination, ultrasound). Then she explained in detail the ultrasound classification of thyroid nodules, indicating the rules of conduct for each type of ultrasound images. The rest of the presentation was focused on the current rules in the field of tumor diagnosis verifying the suspicions of thyroid cancer (changes in biopsy, molecular and genomic tests), and recommended diagnostic followup after oncological treatment in the case of thyroid cancer. Then A. Kowalska MD, PhD, discussed the epidemiology and diagnostic principles of adrenocortical carcinoma. The lecture ended with practical guidance given by the speaker on how to proceed in cases of suspected endocrine tumors (when and how to prepare a referral to a specialist and when the DiLO card).

The next presentation given by Sławomir Okła $\mathrm{MD}, \mathrm{PhD}$, Head of the Department of Otolaryngology, Head and Neck Surgery of the HCC, concerned tumors located in the head and neck. The speaker presented different types of cancer that occur in this location, their specific and nonspecific symptoms, and recommended diagnostics to be performed by the attending PHC physician. One by one he discussed the rules of therapeutic conduct in specific types of cancer, and rules and time limits for the recommended checkups after anticancer therapy. The presentation included a large number of photos and films depicting head and neck cancer, which can increase the oncological alertness of the PHC physician in the case of similar changes in these anatomical areas among patients who are put on the active list of the doctor.
Another thematic block included hematological tumors presented by a team of doctors from the Hematology and Bone Marrow Transplantation Clinic of the HCC. Initially, information about proliferative diseases of the lymphatic system was discussed by Paweł Steckiewicz MD. He explained symptoms of this system - lymphadenopathy and splenomegaly. Then he characterized the basic epidemiological data, classifications and clinical features of non-Hodgkin lymphoma, chronic lymphocytic leukemia, Hodgkin lymphoma and multiple myeloma.

Problematic aspects of anemia were introduced by Elżbieta Kędzierawska MD. During her lecture she characterized divisions (pathogenic and morphological) and classifications of this indication, the main symptoms and primary diagnosis of macrocytic, normocytic and microcytic anemia. The speaker specifically referred to the diagnostic possibilities in this respect, which are the responsibility of the PHC physicians, in accordance with the provisions of the Ordinance of the Minister of Health on the list of guaranteed services in the field of primary health care [3], as amended [4].

The closing lecture belonged to Agatha Obara MD, and concerned acute leukemias. The speaker started by discussing their division (into lymphoblastic and myeloid leukemia) and symptoms for different types of cancer (including leukostasis symptoms, signs of infiltration of organs by leukemia cells, abdominal pain and peritoneal signs and laboratory abnormalities). Then she presented the principles of laboratory diagnostics and invasive diagnosis of acute myeloid leukemia and acute lymphoblastic leukemia.

The closing lecture of each series of training sessions was the presentation made by the HCC organizations with respect to the Oncological Package. The speaker, Michał Chrobot MSc, Head of the Department of Contracting, Accounting and Medical Statistics HCC, in the first part of his presentation explained the general principles of delivering the Oncological Package in the Holycross Cancer Center. Then he presented a list of specialist clinics within the HCC together with a range of cancer types diagnosed in each of the clinics and the activities carried out by the HCC in order to increase the availability of diagnostics and treatment for patients with DiLO cards in the HCC. In the next part of the lecture he recalled the main objectives of the Oncological Package and rules for issuing of the DiLO cards by PHC physician (step by step) [2].

Each meeting ended with a discussion between participants and speakers regarding presented topics from the field of oncology and implementation of the Oncological Package and providing training materials. Strong interest expressed by PHC physicians in the series of training sessions on "oncological sensitivity", confirmed by numerous participants, means 
the issue of organizing future training by specialists from the Holycross Cancer Center, facilitating cooperation between PHC physicians and the Holycross Cancer Center, is left still as an open question.

\section{References}

1. Journal of Laws of 2014, item 1138.

2. http://pakietonkologiczny.gov.pl.

3. Journal of Laws of 2013, item 1248

4. Journal of Laws of 2014, item 1914.

\section{Address for correspondence:}

\section{Ewa Błaszkiewicz}

Department of Education

Jan Kochanowski University

ul. Żeromskiego 5, 25-369 Kielce, Poland

Phone: +48 413497347

E-mail: ewa.blaszkiewicz@ujk.edu.pl 